\title{
The effectiveness of honey for symptomatic relief in upper respiratory tract infections: A systematic review and meta-analysis
}

\author{
Hibatullah Abuelgasim (ORCID iD 0000-0002-2498-090X) medical student, Medical \\ Sciences Division, University of Oxford, United Kingdom. \\ Charlotte Albury (ORCID iD 0000-0002-1036-6626) NIHR SPCR trainee, Nuffield \\ Department of Primary Care Health Sciences, Radcliffe Observatory Quarter, Woodstock \\ Road, Oxford, United Kingdom, OX2 6GG.
}

Joseph J Lee (ORCID iD 0000-0002-4033-0915) NIHR SPCR Career Progression Fellow, Nuffield Department of Primary Care Health Sciences, Radcliffe Observatory Quarter, Woodstock Road, Oxford, United Kingdom, OX2 6GG.

\section{Word count 3106}

Sources of support $\quad$ No other funding was received for this review.

Corresponding author Hibatullah Abuelgasim hiba.abuelgasim@gmail.com

\begin{abstract}
Background: Antibiotic over-prescription for upper respiratory tract infections (URTIs) in primary care exacerbates anti-microbial resistance. There is a need for effective alternatives to antibiotic prescribing. Honey is a lay remedy for URTIs, and has an emerging evidence base for its use. Honey has anti-microbial properties and guidelines recommended honey for acute cough in children.
\end{abstract}

Objectives: To evaluate the effectiveness of honey for symptomatic relief in URTIs.

Methods: A systematic review and meta-analysis. We searched Pubmed, Embase, Web of Science, AMED, Cab abstracts, Cochrane Library, LILACS and CINAHL with a combination of keywords and MeSH terms.

Results: We identified 1345 unique records, and 14 studies were included. Overall risk of bias was moderate. Compared to usual care, honey improved combined symptom score (3 studies, mean difference $-3.96,95 \%$ CI -5.42 to $-2.51, \mathrm{I}^{2}=0 \%$ ), cough frequency ( 8 studies, standardised mean difference (SMD) $-0.36,95 \%$ CI -0.50 to $-0.21, \mathrm{I}^{2}=0 \%$ ), and cough severity, (5 studies, SMD -0.44 , $95 \% \mathrm{CI}-0.64$ to $\left.-0.25, \mathrm{I}^{2}=20 \%\right)$. We combined two studies comparing honey to placebo for relieving combined symptoms, SMD $-0.6395 \%$ CI -1.44 to $0.18, \mathrm{I}^{2}=90 \%$. 
Conclusions: Honey is superior to usual care for the improvement of symptoms of upper respiratory tract infections. It provides a widely available and cheap alternative to antibiotics. Honey could help efforts to slow the spread of antimicrobial resistance, but further high-quality placebo-controlled trials are needed.

Trial registration: study ID: CRD42017067582 on PROSPERO: International prospective register of systematic reviews (https://www.crd.york.ac.uk/prospero/).

\section{SUMMARY BOX}

\section{What is already known about this subject?}

- Honey is a well-known lay therapy for symptoms of upper respiratory tract infections (URTIs); other medications for URTIs are ineffective and can have harmful side-effects

- The use of antibiotics for URTIs is a particular problem, because they are ineffective, and contribute to antimicrobial resistance

- A Cochrane systematic review found that honey can improve cough in children; honey has not been systematically reviewed for other URTI symptoms, or in other patient groups

\section{What are the new findings?}

- Honey is more effective than usual care alternatives for improving URTI symptoms, particularly cough frequency and cough severity

- Comparisons with placebo are more limited, and require more high-quality, placebocontrolled trials

\section{How might it impact on clinical practice in the foreseeable future?}

- There are currently very few effective options that clinicians can prescribe for URTIs

- Honey can be used as an alternative to antibiotics by clinicians who wish to prescribe for URTIs, which can help to combat antimicrobial resistance

\section{INTRODUCTION}

Upper respiratory tract infections (URTIs) are the most frequent reason for antibiotic prescription(1). Since the majority of URTIs are viral, antibiotic prescription is both ineffective(2,3), and inappropriate(4). However, a lack of effective alternatives, as well as a desire to preserve the patientdoctor relationship, both contribute to antibiotic over-prescription(5,6). Antibiotic overuse is a key driver of antimicrobial resistance (AMR)(7), rated by the UK government as one of the top 10 risks facing Britain(8). Furthermore, drug-resistant infections are associated with worse patient outcomes than antibiotic-susceptible infections(9), underlining the impact of AMR on individual patients. 
Honey is a well-known traditional therapy for URTI symptoms. Guidelines recommend it for acute cough in children(10) but the evidence base for honey use for other URTI symptoms and populations has not been evaluated. We therefore systematically reviewed the use of honey for the resolution of symptoms associated with URTIs, in patients of all ages, in any setting.

\section{METHODS}

The protocol for this systematic review was prospectively published https://www.crd.york.ac.uk/prospero/ (study ID: CRD42017067582).

\section{Information sources and search}

We searched Pubmed, Embase, Web of Science, AMED, Cab abstracts, Cochrane Library, LILACS and CINAHL with a combination of keywords and MeSH terms (Supplementary Material, Extended Methods). The search was updated on 18/03/2019. The search strategy was developed with an information specialist and experts reviewed search terms. No language or date restrictions were applied. We also hand-searched the bibliographies of included studies for relevant studies. The search strategy included atopic conditions, but we present here findings for URTIs only. The results for atopic conditions will be published separately.

\section{Study selection}

Studies eligible for inclusion had to meet the following criteria:

1. Randomised clinical trials or in vivo observational studies;

2. Patients of any age and gender, in any setting, with clinically- or laboratory-diagnosed infectious and atopic upper respiratory tract (URT) conditions;

3. Comparing honey (of any type, administered in any way, alone or in conjunction with other treatments) with at least one other group (no treatment, placebo or usual therapy) for the treatment of URT symptoms.

We excluded: in vitro studies; animal studies; protocol-only publications; case reports; case series and studies without an appropriate comparator.

We defined URTIs as acute infections of the respiratory tract, including acute cough, colds and influenza-like illness, but excluding bronchitis or other infection of the lower respiratory tract. We also excluded ear infections without other URTI symptoms and infections following surgical or medical interventions. We included any commonly used treatments under 'usual care'.

Two reviewers (HA and either JJL or CA) screened each citation at the title and abstract, and full text. We discussed discrepancies, and if unresolved, the remaining reviewer (JJL or CA) adjudicated. 


\section{Data extraction and risk of bias assessment}

Data were extracted by HA checked by a second reviewer. Where studies were not published in English, native speakers of the appropriate language translated them. If studies did not report required details, we requested data from study authors, and where possible estimated from published data; full methods for estimation can be found in the supplementary material (Supplementary Table 1). Two reviewers (HA and JL) assessed risk of bias with the Cochrane Risk of Bias Tool. Each study was assessed with regard to the following bias domains: selection, performance, detection, attrition, reporting, and other. Other was defined in the Cochrane Handbook as "bias due to problems not covered elsewhere" in the bias domains(11). We planned to use funnel plots and Eggers test to examine risk of publication bias if there were sufficient studies.

\section{Statistical methods}

We used RevMan 5.3 software(12) to undertake random effects meta-analysis. Where studies used the same outcome measure, such as a validated questionnaire, we estimated mean differences (MDs) in symptom scores before and after intervention, with $95 \%$ confidence intervals. We estimated standard mean difference (SMD) with 95\% confidence intervals, for studies that used different scales. We used odds ratios with $95 \%$ confidence intervals for binary outcomes. The $\mathrm{I}^{2}$ statistic was our measure of statistical heterogeneity.

We compared honey to usual care and undertook subgroup analyses of the different types of usual care. There are no effective active treatments for URTIs, but many commonly used remedies. We therefore combined ineffective remedies as 'usual care' but also undertook sensitivity analyses of the different substances to support this approach.

We undertook sensitivity analyses excluding studies where mean differences had to be estimated using extra calculations or assumptions (Supplementary Table 1).

\section{Patient and public involvement}

This research was conducted without patient involvement.

\section{RESULTS}

\section{Study selection}

The search identified 1345 unique records and we excluded 1241 records at the titles-and-abstracts stage (Figure 1). After full-text screening, a further 84 studies were excluded with reasons (Supplementary Table 2). Here, we report results for the 14 studies of upper respiratory tract infections. 
Study characteristics

\begin{tabular}{|c|c|c|c|c|c|}
\hline Study & Design & Age range & Intervention & Comparator & Outcome measure \\
\hline $\begin{array}{l}\text { Ahmadi } \\
\text { 2013(13) }\end{array}$ & $\begin{array}{l}\mathrm{RCT} \\
\text { Double-blind }\end{array}$ & $2-5$ years & Honey & Diphenhydramine & $\begin{array}{l}\text { Day-time and night-time } \\
\text { cough frequency and } \\
\text { severity (we converted this } \\
\text { to a 3-point Likert scale) }\end{array}$ \\
\hline $\begin{array}{l}\text { Ayazi } \\
2017(14)\end{array}$ & $\begin{array}{l}\text { RCT } \\
\text { No blinding }\end{array}$ & $1-12$ years & $\begin{array}{l}\text { Honey } 1 ; \\
\text { Honey } 2\end{array}$ & Diphenhydramine & $\begin{array}{l}\text { Nocturnal cough and sleep } \\
\text { difficulty score (validated 5- } \\
\text { item 7-point Likert } \\
\text { scale(24)) }\end{array}$ \\
\hline $\begin{array}{l}\text { Canciani } \\
2014(19)\end{array}$ & $\begin{array}{l}\text { RCT } \\
\text { Double-blind }\end{array}$ & $3-6$ years & Grintuss $^{\mathrm{TM}}$ syrup & Placebo & $\begin{array}{l}\text { Day-time and night-time } \\
\text { cough severity (modified } \\
\text { from validated } \\
\text { questionnaire }(27) \text { ) }\end{array}$ \\
\hline $\begin{array}{l}\text { Cohen } \\
2012(20)\end{array}$ & $\begin{array}{l}\text { RCT } \\
\text { Double-blind }\end{array}$ & $1-5$ years & $\begin{array}{l}\text { Eucalyptus honey; } \\
\text { Citrus honey; } \\
\text { Labiatae honey }\end{array}$ & $\begin{array}{l}\text { Placebo (silan date } \\
\text { extract) }\end{array}$ & $\begin{array}{l}\text { Cough score (validated 5- } \\
\text { item 7-point Likert } \\
\text { scale(24)), effect on sleep } \\
\text { and combination }\end{array}$ \\
\hline $\begin{array}{l}\text { Cohen } \\
2017(21)\end{array}$ & $\begin{array}{l}\text { RCT } \\
\text { Single-blind }\end{array}$ & $2-5$ years & Grintuss $^{\mathrm{TM}}$ syrup & Carbocysteine syrup & $\begin{array}{l}\text { Cough score (validated 5- } \\
\text { item 7-point Likert } \\
\text { scale(24)) }\end{array}$ \\
\hline $\begin{array}{l}\text { Gupta } \\
2016(22)\end{array}$ & $\begin{array}{l}\text { RCT } \\
\text { Double-blind }\end{array}$ & 18-65 years & $\begin{array}{l}\text { Honitus cough } \\
\text { syrup }\end{array}$ & $\begin{array}{l}\text { Marketed cough } \\
\text { syrup, containing } \\
\text { diphenhydramine }\end{array}$ & $\begin{array}{l}\text { Day-time and night-time } \\
\text { cough frequency score (6- } \\
\text { point Likert scale), throat } \\
\text { irritation }\end{array}$ \\
\hline $\begin{array}{l}\text { Miceli Sopo } \\
2015(18)\end{array}$ & $\begin{array}{l}\text { RCT } \\
\text { No blinding }\end{array}$ & $2-14$ years & $\begin{array}{l}\text { Wildflower honey + } \\
\text { milk }\end{array}$ & $\begin{array}{l}\text { Dextromethorphan; } \\
\text { Levodropropizine }\end{array}$ & $\begin{array}{l}\text { Cough score (validated 5- } \\
\text { item 7-point Likert } \\
\text { scale }(24) \text { ) }\end{array}$ \\
\hline $\begin{array}{l}\text { Nanda } \\
2017(23)\end{array}$ & $\begin{array}{l}\text { RCT } \\
\text { Blinding } \\
\text { unclear }\end{array}$ & $>18$ years & $\begin{array}{l}\text { Honey + supportive } \\
\text { treatments }\end{array}$ & $\begin{array}{l}\text { Supportive treatments } \\
\text { only (regarded as } \\
\text { placebo) }\end{array}$ & $\begin{array}{l}\text { Subjective symptom score, } \\
\text { throat pain recovery, fever } \\
\text { recovery }\end{array}$ \\
\hline Paul 2007(24) & $\begin{array}{l}\text { RCT } \\
\text { Partially } \\
\text { double-blind } \\
\end{array}$ & $2-18$ years & Buckwheat honey & $\begin{array}{l}\text { Dextromethorphan; } \\
\text { No treatment }\end{array}$ & $\begin{array}{l}\text { Cough score (5-item 7-point } \\
\text { Likert scale) }\end{array}$ \\
\hline $\begin{array}{l}\text { Pourahmad } \\
2009(25)\end{array}$ & $\begin{array}{l}\text { Single blinded } \\
\text { trial }\end{array}$ & $\begin{array}{l}\text { Mean age } \\
27.4 \mathrm{SD} 6.2\end{array}$ & $\begin{array}{l}\text { Honey }+ \\
\text { paracetamol, } \\
\text { naproxen and } \\
\text { chlorpheniramine }\end{array}$ & $\begin{array}{l}\text { Paracetamol, naproxen } \\
\text { and chlorpheniramine }\end{array}$ & $\begin{array}{l}\text { Duration of signs and } \\
\text { symptoms: rhinitis, muscle } \\
\text { pain, fever, throat } \\
\text { congestion, cough and } \\
\text { sneezing, assessed by } \\
\text { investigators }\end{array}$ \\
\hline $\begin{array}{l}\text { Raeessi } \\
2011(26)\end{array}$ & $\begin{array}{l}\text { RCT } \\
\text { Double-blind }\end{array}$ & 21-65 years & $\begin{array}{l}\text { Honey; } \\
\text { Honey + coffee }\end{array}$ & Coffee & $\begin{array}{l}\text { Cough frequency } \\
\text { (questionnaire) }\end{array}$ \\
\hline $\begin{array}{l}\text { Raeessi } \\
2013(15)\end{array}$ & $\begin{array}{l}\text { RCT } \\
\text { Double-blind }\end{array}$ & 21-65 years & Honey + coffee & $\begin{array}{l}\text { Prednisolone; } \\
\text { Guaifenesin (regarded } \\
\text { as placebo) }\end{array}$ & $\begin{array}{l}\text { Cough frequency } \\
\text { (questionnaire) }\end{array}$ \\
\hline $\begin{array}{l}\text { Shadkam } \\
2010(16)\end{array}$ & $\begin{array}{l}4 \text { arm RCT } \\
\text { No blinding }\end{array}$ & $\begin{array}{l}24-60 \\
\text { months }\end{array}$ & Honey & $\begin{array}{l}\text { Dextromethorphan; } \\
\text { Diphenhydramine; } \\
\text { Supportive treatments } \\
\text { also suggested to the } \\
\text { other groups, } \\
\text { including saline nasal } \\
\text { drops and paracetamol }\end{array}$ & $\begin{array}{l}\text { Cough score (validated 5- } \\
\text { item 7-point Likert } \\
\text { scale(24)) }\end{array}$ \\
\hline $\begin{array}{l}\text { Waris } \\
2014(17)\end{array}$ & $\begin{array}{l}\text { RCT } \\
\text { Double-blind }\end{array}$ & $1-12$ years & Honey & $\begin{array}{l}\text { Salbutamol syrup; } \\
\text { Placebo (brown- } \\
\text { coloured sugar syrup) }\end{array}$ & $\begin{array}{l}\text { Cough score (validated 5- } \\
\text { item 7-point Likert } \\
\text { scale(24)) }\end{array}$ \\
\hline
\end{tabular}


We included 14 studies in the qualitative analysis, all of which were RCTs(13-26). Study characteristics are summarised in Table 1. Eight studies were paediatric only. There was considerable diversity of 'usual care' interventions (Table 1, Supplementary Table 3), and while nine studies used pure honey, two used Grintuss ${ }^{\circledR} \operatorname{syrup}(19,21)$ (a cough suppressant syrup containing honey and plant complexes) and one used Honitus syrup (an Ayeverdic honey-based syrup containing herb extracts) (22). Additionally, two combined honey with coffee $(15,26)$, and one with milk(18). We evaluated all of these as 'honey' interventions. Twelve studies could be combined in meta analyses(13-16,1824,26). Outcome measures were diverse (Table 1). The commonest were measures of cough. Six studies measured cough with validated scores $(13,15,16,25,23,24)$, three used modified or unvalidated scores $(14,17,19)$ and three used questionnaires $(12,21,22)$. Apart from cough symptoms, studies also included outcomes for sleep difficulty(13), overall subjective symptoms(18) and duration of a combination of rhinitis, myalgia, congestion and cough assessed by investigators(20). Full study characteristics are in the supplementary material (Supplementary Table 4).

\section{Risk of bias within studies}

Figure 2 and Table 2 summarise our risk of bias assessments for the included studies. Few studies made mention of specific attempts to minimise other forms of bias. Due to small numbers of studies, we were unable to use funnel plots to assess publication bias.

\begin{tabular}{|l|l|l|l|}
\hline Type of bias & $\underline{\text { Low risk }}$ & $\underline{\text { Unclear risk }}$ & $\underline{\text { High risk }}$ \\
\hline $\begin{array}{l}\text { Selection (random } \\
\text { sequence generation) }\end{array}$ & $9 / 14$ & $2 / 14$ & $3 / 14$ \\
\hline Performance & $6 / 14$ & $3 / 14$ & $5 / 14$ \\
\hline Detection & $8 / 14$ & $2 / 14$ & $4 / 14$ \\
\hline Attrition & $7 / 14$ & $2 / 14$ & $5 / 14$ \\
\hline Reporting & $6 / 14$ & $8 / 14$ & $0 / 14$ \\
\hline Other bias & $12 / 14$ & $0 / 14$ & $2 / 14$ \\
\hline Table 2: Summary of risk of bias assessment & & \\
\hline
\end{tabular}

Table 3 shows the pooled results of the meta-analyses. 


\begin{tabular}{|c|c|c|c|c|c|}
\hline Comparator & Outcome & $\begin{array}{l}\text { Studies } \\
\text { (n) }\end{array}$ & Pooled effect estimate including all studies & $\begin{array}{l}\text { Studies } \\
\text { (n) }\end{array}$ & $\begin{array}{l}\text { Pooled estimates excluding studies with ingredients } \\
\text { other than honey** }\end{array}$ \\
\hline Placebo & Combined symptom score & $2(372)$ & SMD $-0.63,95 \%$ CI -1.44 to $0.18, I^{2}=91 \%$ & $1(270)$ & SMD $-1.0395 \%$ CI -1.32 to -0.75 \\
\hline \multirow{6}{*}{ Usual care } & Combined symptom score & $3(333)$ & $\mathrm{MD}-3.96,95 \% \mathrm{CI}-5.42$ to $-2.51, \mathrm{I}^{2}=0 \%$ & $2(192)$ & MD $-4.4795 \%$ CI -6.47 to $-2.48, \mathrm{I}^{2}=0 \%$ \\
\hline & Cough frequency & $8(832)$ & SMD $-0.36,95 \%$ CI -0.50 to $-0.21, \mathrm{I}^{2}=0 \%$ & $6(586)$ & SMD $-0.4095 \%$ CI -0.58 to $-0.21, \mathrm{I}^{2}=0 \%$ \\
\hline & Cough severity & $5(598)$ & SMD $-0.44,95 \%$ CI $-0.64,-0.25, I^{2}=20 \%$ & $4(457)$ & SMD $-0.4495 \%$ CI -0.70 to $-0.17, \mathrm{I}^{2}=0 \%$ \\
\hline & Improvement & $2(317)$ & OR $1.01,95 \%$ CI 0.45 to $2.27, \mathrm{I}^{2}=56 \%$ & $1(200)$ & OR $0.7395 \%$ CI 0.42 to 1.27 \\
\hline & $\begin{array}{l}\text { Throat pain recovery by } \\
\text { day } 5\end{array}$ & $1(200)$ & OR $0.75,95 \%$ CI 0.43 to 1.32 & & No change \\
\hline & Fever recovery by day 5 & $1(200)$ & OR $2.5895 \%$ CI 1.22 to 5.46 & & No change \\
\hline \multirow{3}{*}{ *Dextromethorphan } & Combined symptom score & $1(68)$ & MD $-2.32,95 \%$ CI -5.88 to 1.24 & & NA \\
\hline & Cough frequency & $2(137)$ & MD $-0.52,95 \%$ CI -1.51 to $0.46, \mathrm{I}^{2}=0 \%$ & & NA \\
\hline & Cough severity & $2(137)$ & MD $-0.56,95 \%$ CI -1.65 to $0.53, \mathrm{I}^{2}=0 \%$ & & NA \\
\hline \multirow{3}{*}{ *Diphenhydramine } & Combined symptom score & $1(87)$ & MD $-5.31,95 \%$ CI -7.96 to -2.67 & & NA \\
\hline & Cough frequency & $4(385)$ & MD $-0.29,95 \%$ CI -0.58 to $-0.01, \mathrm{I}^{2}=46 \%$ & $3(280)$ & $-0.4195 \%$ CI -0.69 to $-0.14, \mathrm{I}^{2}=17 \%$ \\
\hline & Cough severity & $3(280)$ & MD $-0.50,95 \%$ CI -0.88 to $-0.13, \mathrm{I}^{2}=53 \%$ & & NA \\
\hline \multicolumn{6}{|c|}{$\begin{array}{l}\text { Pooled results compare honey, meta-analysed with Mantel-Haenszel random effects models. } \\
\text { Key: Studies number of included studies reporting outcome, } \mathrm{n} \text { total number of participants, OR odds ratio, SMD standard mean difference, MD mean difference, CI confidence } \\
\text { interval, } \chi^{2} \text { Chi-squared statistic, p p-value, NA Not applicable as these studies were not in the primary analysis so results are unchanged. } \\
*=\text { subgroup of usual care } \\
* * \text { Results excluding Cohen } 2017, \text { Gupta } 2016 \text {, Micelli Sopo } 2015 \text {, Canciani } 2014\end{array}$} \\
\hline
\end{tabular}




\section{Honey vs placebo}

Two studies $(19,20)$ compared honey to placebo for cough, on validated Likert scales, and could be combined. Both had low risk of bias, and included a total of 372 patients. Honey was not superior to placebo in improving combined symptoms, and heterogeneity was considerable (Table 3, Supplementary Figure 1). We therefore consider these studies separately. Cohen 2012 estimated a beneficial effect (standardised mean difference -1.03, 95\% CI -1.32 to -0.75) and Canciani 2012 did not (SMD -0.20,95\% CI -0.59 to 0.19). A further study, Waris 2014, could not be included in meta-analysis, but reported that honey reduced combined symptom score significantly more than placebo by the final day of the study (mean difference $=3.99 \mathrm{p}=0.003$ ).

\section{Honey vs usual care}

Combined symptom scores were obtainable from three studies of children $(14,21,24)$ with considerable risk of bias. Cough frequency and cough severity were obtainable from eight(13-16,21,22,24,26) and five studies $(13,14,16,21,24)$, respectively, of variable risk of bias. All three of these symptoms improved significantly more for patients taking honey than usual care, with low statistical heterogeneity (Table 3, Figure 3). Estimates were consistent with comparisons to placebo. Two studies with high risk of bias including 317 patients could be combined into the binary outcome measure 'improvement'. There was moderate heterogeneity and honey was not significantly different to usual care (Table 2 , Supplementary Figure 2).

One study could not be included in meta-analyses. Pourahmad (2009) was excluded because mean differences in symptom scores were not reported. Instead, the duration of signs and symptoms of the common cold (which were not detailed) were given. The symptoms of patients who received honey lasted 1-2 days shorter than those who received usual care. No confidence intervals or p-values were reported.

The usual care group was split into subgroups comparing honey to dextromethorphan, and diphenhydramine.

\section{Honey vs dextromethorphan}

Two studies(16,24) were combinable, including a total of 137 patients. Only one reported combined symptom score(24), but both reported cough frequency and cough severity. Both studies had a relatively high risk of bias. Honey was not significantly better than dextromethorphan for improvement of combined symptoms (MD -2.32, 95\% CI -5.88 to 1.24 ), cough frequency (MD - $0.52,95 \% \mathrm{CI}-1.51$ to $0.46, \mathrm{I}^{2}=0 \%$ ) or cough severity (MD $-0.56,95 \% \mathrm{CI}-1.65$ to $0.53, \mathrm{I}^{2}=0 \%$ ) but results were consistent with overall usual care. (Table 3, Supplementary Figure 3). 


\section{Honey vs diphenhydramine}

Four studies $(13,14,16,22)$ were combinable, including a total of 385 patients. Only one reported combined symptom score(14), but all three reported cough frequency, and two reported cough severity. One study(13) was of low risk of bias; the other three had moderate(22) or relatively high(14,16) risk of bias. Honey was significantly better than diphenhydramine for improvement of all three outcomes (Combined symptom score MD -5.31, 95\% CI -7.96 to -2.67, cough frequency MD -0.29, 95\% CI - 0.58 to $0.01, \mathrm{I}^{2}=46 \%$, MD $-0.50,95 \%$ CI -0.88 to $-0.13, \mathrm{I}^{2}=53 \%$, Table 3, Supplementary Figure 4).

\section{Sensitivity analyses}

In order to assess the evidence for effects in adults, we performed further analyses restricted to the four studies with an adult population (Supplementary Table 4)(15,22,23,26). Only one pooled comparison of three studies could be made, honey versus usual care for cough frequency (SMD -0.19, 95\% CI -0.47 to $0.09, \mathrm{I}^{2}=4 \%$ ). There was evidence from single studies as well. Nanda 2017 estimated that at 5 days there was no difference in throat congestion (OR $0.73,95 \%$ CI 0.42 to 1.27), throat pain (OR $0.75,95 \%$ CI 0.43 to 1.32 ) or complete satisfaction (which was linked to throat pain, OR $1.4495 \%$ CI 0.72 to 2.86), but more people had recovered from fever (OR $2.5895 \%$ CI 1.22 to 5.46). In addition, Pourahmad 2009 included adults, and reported a statistically shorter time to clinical recovery from the common cold(25). Gupta 2016 included adults, and reported an increased proportions of patients with at least a 75\% improvement in throat irritation at day four (OR for failure $0.2295 \%$ CI 0.08 to 0.59$)$.

We performed sensitivity analyses excluding studies where we had to estimate elements of the results (Canciani 2014, Ahmadi 2013, Raeessi 2011, Raeessi 2013). For the comparison with placebo, the one remaining study (20) found honey was significantly better than placebo, SMD $=-1.03(-1.32$ to -0.75 , low risk of bias).

In the comparison with usual care, the reductions in cough frequency and cough severity remained statistically significant: cough frequency SMD $=-0.30,95 \% \mathrm{CI}(-0.47$, to -0.12$), \mathrm{I}^{2}=0 \%$; cough severity $\mathrm{SMD}=-0.43(-0.69$ to -0.17$), \mathrm{I}^{2}=38 \%$.

In the subgroup comparison with diphenhydramine, SMD in cough frequency was $-0.16(-0.42$ to $0.10)$, and $\mathrm{I}^{2}$ dropped from $17 \%$ to $3 \%$. For cough severity, SMD decreased to -0.51 (-1.24 to 0.22$)$, while $\mathrm{I}^{2}$ rose to $77 \%$.

We performed further sensitivity analyses excluding studies with interventions combining honey with other ingredients not included in the comparator arm (Cohen 2017, Gupta 2016, Miceli Sopo 2015, Canciani 2014, Table 3). This made little difference to the estimates. For the comparison with usual 
care, combined symptom score was reduced in the honey arms of the two remaining studies by a mean difference of $-4.47\left(-6.47\right.$ to $\left.-2.48, \mathrm{I}^{2}=0 \%\right)$. Removing Miceli Sopo 2015 from the overall 'improvement' category left only Nanda 2017, which also estimated no effect (OR 0.73 95\% CI 0.42 to 1.27). Removing Cohen 2017 from the assessment of cough frequency gave a standard mean difference of -0.40 (95\% CI -0.58 to $-0.21, \mathrm{I}^{2}=0 \%$ ). Removing Cohen 2017 from the cough severity outcome analysis had no impact on the point estimate (Standardised mean difference $-0.44,95 \%$ CI 0.07 to $-0.17, \mathrm{I}^{2}=0 \%$ ). In the subgroup analysis of diphenhydramine vs honey, with the outcome of cough frequency, the point estimate and confidence intervals moved further from the line of no-effect, with reduced heterogeneity $\left(-0.4195 \%\right.$ CI -0.69 to $\left.-0.14, \mathrm{I}^{2}=17 \%\right)$

\section{DISCUSSION}

Assessing all the available literature, we found evidence that honey appears to improve URTI symptoms more effectively than usual care, but comparisons to placebo were limited. We could combine only two placebo-controlled studies in meta-analysis, and these used honey and a honey-containing syrup. The pooled result had considerable heterogeneity (91\%). This may represent differences between the interventions. A sensitivity analysis excluding the syrup indicated a beneficial effect of honey on cough, but this was based on a single study. Two of the three studies comparing honey to placebo indicated a beneficial effect of honey, but overall we do not have a strong evidence base from comparisons of honey against matched placebo.

In comparison with usual care, honey was associated with significantly greater reduction in combined symptom score, cough frequency and cough severity (Table 2). The low heterogeneity in these comparisons $\left(\mathrm{I}^{2}=0 \%\right.$ for combined symptoms and cough frequency, $20 \%$ for cough severity) suggested that despite the variety of usual care treatments used by these studies, all were similarly ineffective. These estimates were consistent with estimates from comparison to placebo. The persistence of the effect size in the sensitivity analyses, despite a reduction in statistical power, implied that the effect size was robust, strengthening the evidence in favour of honey and supported our analysis strategies.

The apparent effect of honey was further supported by subgroup analyses. The results with diphenhydramine (Supplementary Figure 4) were consistent with dextromethorphan (Supplementary Figure 3), for the improvement of all three outcomes. The dextromethorphan comparison was nonsignificant, but included only two studies $(16,24)$, with only one reporting combined symptoms. Similarly, in the dichotomous outcome, 'improvement', honey was not significantly better than usual care (Table 2). As well as a loss of statistical power in dichotomising outcomes an explanation for this could be that it was the wrong question to ask. The self-limiting nature of URTIs results in a general trend of improvement in symptoms even in the control groups. The difference, therefore, between control and intervention groups is likely to be in degree of recovery. 
Previous reviews have included children and focussed on cough. Our broader inclusion criteria have allowed us to identify the more limited data for adults, both in terms of numbers of studies and effectiveness, and for symptoms such as sore throat.

\section{Strengths and limitations}

A strength of this review was our comprehensive search strategy, which means we are unlikely to have missed any relevant studies. To our knowledge, this is the most comprehensive systematic review evaluating honey for the improvement of a range of URTI symptoms.

A limitation was the risk of bias in included studies. The risk of bias was variable, and we did not assess study quality in other ways. There was limited information on how patients in the placebo arms were asked not to take honey, and how their adherence was measured. This is a weakness, and if honey were effective this would bias the effect towards the null. There were also missing data, however we estimated missing values where it was possible and appropriate, allowing the pooling of studies that could not otherwise have been synthesised. We did this to include as much as possible, but the weaknesses of this approach are a loss of data and including studies which tended to be smaller and at a higher risk of bias. This may explain why the dichotomised outcome 'improvement' showed no effect compared to usual care, whereas using the combined symptom score detected a statistically significant effect.

The broad nature of our inclusion criteria, while necessary to maximise the scope of eligible studies, also resulted in considerable variability in interventions. Most studies included in the meta-analyses did evaluate pure honey, but Grintuss ${ }^{\circledR} \operatorname{syrup}(19,21)$, Honitus $\operatorname{syrup}(22)$, honey combined with milk(18), and coffee $(15,26)$ were also used, and we evaluated these as 'honey' interventions. A disadvantage of including these studies is difficulty knowing how much of any effect is due to the honey, and how much might be due to the other ingredients. We included these studies because could find no clinical evidence of effectiveness of the other ingredients. Honey is itself a complex and heterogeneous substance; DNA analysis has shown it contains plant material from multiple taxa.(28) The 'usual care' interventions were also highly varied and could have had different effects. Some studies used comparators that attempted to replicate the look and consistency of honey. If the effect of honey is mediated through forming a soothing mechanical barrier, then these comparators could have a similar effect to honey, biasing the results towards the null. On the other hand, studies that made less of an attempt to blind patients to their allocation risk biased reporting and patients taking honey outside of the trial context, with less predictable results. The low heterogeneity of our results, and our sensitivity analyses are reassuring. Finally, we could not explore the effectiveness of different types or doses of honey due to a lack of data. 


\section{Implications for clinicians and policymakers}

Exiting research shows that most usual care therapies produce no, or relatively small, improvement in URTI symptoms(29,30). Antibiotics, which are frequently prescribed despite guidance, are associated with significant adverse effects in children and adults(2,3,31). Given that a lack of alternative therapies(6) and a desire to preserve the patient-doctor relationship(5) are two key contributors to GP antibiotic over-prescription, our finding that honey may be effective is important in the clinical context: honey is a reasonable alternative. Adverse effects were not observed in most patients given honey, and they were relatively mild, such as nausea. Honey is commercially consumed and is safe for use by the majority of the population, apart from allergic individuals and infants under one year of age.(32) Data on the use of honey and other complementary and alternative medicines in the UK, and doctors' and patients' perceptions of these therapies, are limited. However, the low cost and easy accessibility of honey would likely contribute to the acceptability of this treatment to patients, clinicians, and policymakers. Because of the limitations to the evidence, particularly for adults, we would support large, high quality placebo-controlled trials.

\section{Conclusion}

We found that honey likely improves URTI symptoms, with the strongest evidence in the context of cough frequency and cough severity. Moderate evidence supports its use in preference to usual care for other URTI symptoms, and most evidence comes from studies of children. Honey is a frequently used lay remedy that is well-known to patients. It is also cheap, easy to access, and has limited harms. When clinicians wish to prescribe for URTI, we would recommend honey as an alternative to antibiotics. Honey is more effective and less harmful than usual care alternatives and avoids causing harm through anti-microbial resistance.

\section{ACKNOWLEDGEMENTS}

Many thanks to Filippo Bianchi, Kerstin Frei, Milad Sherafati and Marina Al Basri for translating, and Nia Roberts for training and reviewing the search strategy. Thanks to Merlin Wilcox for sharing search terms and Oliver Van Hecke for reviewing search terms.

\section{COMPETING INTERESTS}

Joseph J. Lee is a hobby beekeeper. There are no other conflicts of interest.

\section{FUNDING}

Hibatullah Abuelgasim - medical student, University of Oxford.

Charlotte Albury - NIHR SPCR trainee. 
Joseph J. Lee - NIHR SPCR Career Progression Fellow.

No other funding was received for this review.

\section{LEGENDS}

\section{MAIN TEXT}

Figure 1: PRISMA flow diagram outlining the process of study selection.

Figure 2: Summary of risk of bias assessment for included studies.

Figure 3: Forest plots for changes in combined symptoms score, cough frequency and cough severity when patients are treated with honey vs usual care.

Table 1: Summary of characteristics of included studies

Table 2: Summary of risk of bias assessment

Table 3: Summary of results of meta-analyses

\section{SUPPLEMENTARY MATERIAL}

Supplementary Figure 1: Forest plot for changes in combined symptom score when patients are treated with honey vs placebo.

Supplementary Figure 2: Forest plot for our devised binary outcome, 'improvement', when patients are treated with honey vs usual care.

Supplementary Figure 3: Forest plots for changes in combined symptom score, cough frequency and cough severity when patients are treated with honey vs dextromethorphan.

Supplementary Figure 4: Forest plots for changes in combined symptom score, cough frequency and cough severity when patients are treated with honey vs diphenhydramine.

Supplementary Table 1: Detailed methods for MD and SD estimation in the relevant studies

Supplementary Table 2: Reasons for exclusion at full text screening

Supplementary Table 3: Summary of usual care interventions in "infectious" group studies

Supplementary Table 4: Study characteristics

Supplementary Table 5: Studies with adults only

\section{BIBLIOGRAPHY}


1. Goossens H, Ferech M, Vander Stichele R, Elseviers M. Outpatient antibiotic use in Europe and association with resistance: a cross-national database study. Lancet [Internet].

2005;365(9459):579-87. Available from:

https://www.sciencedirect.com/science/article/pii/S0140673605179070

2. Kenealy T, Arroll B. Antibiotics for the common cold and acute purulent rhinitis. Cochrane database Syst Rev. 2013;(6):CD000247.

3. Arroll B. Common cold. BMJ Clin Evid [Internet]. 2011;2011:1510. Available from: http://www.ncbi.nlm.nih.gov/pmc/articles/PMC3275147/

4. Hersh AL, Jackson MA, Hicks LA. Principles of Judicious Antibiotic Prescribing for Upper Respiratory Tract Infections in Pediatrics. Pediatrics [Internet]. 2013;132(6):1146-54.

Available from: http://pediatrics.aappublications.org/content/132/6/1146.abstract

5. Kumar S, Little P, Britten N. Why do general practitioners prescribe antibiotics for sore throat? Grounded theory interview study. BMJ [Internet]. 2003;326(7381):138. Available from: http://www.bmj.com/content/326/7381/138.abstract

6. Bradley CP. Uncomfortable prescribing decisions: a critical incident study. BMJ Br Med J [Internet]. 1992;304(6822):294-6. Available from: http://www.ncbi.nlm.nih.gov/pmc/articles/PMC1881047/

7. Ventola CL. The Antibiotic Resistance Crisis: Part 1: Causes and Threats. Pharm Ther [Internet]. 2015;40(4):277-83. Available from: http://www.ncbi.nlm.nih.gov/pmc/articles/PMC4378521/

8. Tackling drug-resistant infections globally: final report and recommendations [Internet]. The Review on Antimicrobial Resistance. London; 2016 [cited 2018 Jan 1]. Available from: https://amr-review.org/sites/default/files/160525_Final paper_with cover.pdf

9. van Hecke O, Wang K, Lee JJ, Roberts NW, Butler CC. Implications of Antibiotic Resistance for Patients' Recovery From Common Infections in the Community: A Systematic Review and Meta-analysis. Clin Infect Dis [Internet]. 2017 Aug 1;65(3):371-82. Available from: http://dx.doi.org/10.1093/cid/cix233

10. Oduwole O, Meremikwu MM, Oyo-Ita A, Udoh EE. Honey for acute cough in children. Cochrane database Syst Rev. 2014 Dec;(12):CD007094.

11. Higgins JPT, Altman DG, Sterne JAC, (editors). Chapter 8: Assessing risk of bias in included studies. In: Higgins JPT, Green S (editors). Cochrane Handbook for Systematic Reviews of Interventions Version 5.1.0 (updated March 2011) [Internet]. The Cochrane Collaboration; 2011. Available from: www.handbook.cochrane.org

12. The Cochrane Collaboration. Review Manager (RevMan) [computer program]. Version 5.3. Copenhagen Nord Cochrane Cent. 2014;

13. Ahmadi M, Moosavi SM, Zakeri S. Comparison of the effect of honey and diphenhydramine on cough alleviation in 2-5-year-old children with viral upper respiratory tract infection. $\mathrm{J}$ 
Gorgan Univ Med Sci [Internet]. 2013;15(2 PG-):8-13. Available from:

http://ovidsp.ovid.com/ovidweb.cgi?T=JS\&CSC=Y\&NEWS=N\&PAGE=fulltext\&D=caba6\& $\mathrm{AN}=20133348344$

http://oxfordsfx.hosted.exlibrisgroup.com/oxford?sid=OVID:cabadb\&id=pmid:\&id=doi:\&issn $=1562-4765 \&$ isbn $=\&$ volume $=15 \&$ issue $=2 \&$ spage $=P e 8 \&$ pages $=P e 8$ -

Pe12\%2C+En13\&date $=2013 \& \mathrm{t}$

14. Ayazi P, Mahyar A, Yousef-Zanjani M, Allami A, Esmailzadehha N, Beyhaghi T. Comparison of the Effect of Two Kinds of Iranian Honey and Diphenhydramine on Nocturnal Cough and the Sleep Quality in Coughing Children and Their Parents. PLoS One. 2017 Jan;12(1):e0170277.

15. Raeessi MA, Aslani J, Raeessi N, Gharaie H, Karimi Zarchi AA, Raeessi F. Honey plus coffee versus systemic steroid in the treatment of persistent post-infectious cough: a randomised controlled trial. Prim Care Respir J. 2013 Sep;22(3):325-30.

16. Shadkam MN, Mozaffari-Khosravi H, Mozayan MR. A Comparison of the Effect of Honey, Dextromethorphan, and Diphenhydramine on Nightly Cough and Sleep Quality in Children and Their Parents. J Altern Complement Med. 2010 Jul;16(7):787-93.

17. Waris A, Macharia M, Njeru EK, Essajee F. Randomised double blind study to compare effectiveness of honey, salbutamol and placebo in treatment of cough in children with common cold. East Afr Med J. 2014 Feb;91(2):50-6.

18. Miceli Sopo S, Greco M, Monaco S, Varrasi G, Di Lorenzo G, Simeone G. Effect of multiple honey doses on non-specific acute cough in children. An open randomised study and literature review. Allergol Immunopathol (Madr). 2015;43(5):449-55.

19. Canciani M, Murgia V, Caimmi D, Anapurapu S, Licari A, Marseglia GL. Efficacy of Grintuss $(\mathrm{R})$ pediatric syrup in treating cough in children: a randomized, multicenter, double blind, placebo-controlled clinical trial. Ital J Pediatr. 2014 Jun;40:56.

20. Avner Cohen H, Rozen J, Kristal H, Laks Y, Berkovitch M, Uziel Y, et al. Effect of Honey on Nocturnal Cough and Sleep Quality: A Double-blind, Randomized, Placebo-Controlled Study. Pediatrics [Internet]. 2012;130(3):465-71. Available from: http://search.ebscohost.com/login.aspx?direct=true \&db=cin20\&AN=108150000\&site=ehostlive

21. Cohen HA, Hoshen M, Gur S, Bahir A, Laks Y, Blau H. Efficacy and tolerability of a polysaccharide-resin-honey based cough syrup as compared to carbocysteine syrup for children with colds: a randomized, single-blinded, multicenter study. World J Pediatr. 2017 Feb;13(1):27-33.

22. Gupta A, Gaikwad V, Kumar S, Srivastava R, Sastry JLN. Clinical validation of efficacy and safety of herbal cough formulation "Honitus syrup" for symptomatic relief of acute nonproductive cough and throat irritation. Ayu [Internet]. 2016;37(3/4):206-14. Available from: 
http://www.ayujournal.org/article.asp?issn=0974-8520

23. Nanda MS, Mittal SP, Gupta V. Role of honey as adjuvant therapy in patients with sore throat. Natl J Physiol Pharm Pharmacol [Internet]. 2017;7(4):412-5. Available from:

http://ovidsp.ovid.com/ovidweb.cgi?T=JS\&CSC=Y\&NEWS=N\&PAGE=fulltext\&D=emex \& $\mathrm{AN}=615171168$

http://oxfordsfx.hosted.exlibrisgroup.com/oxford?sid=OVID:embase\&id=pmid:\&id=doi:10.54 55\%2Fnjppp.2017.7.1233125122016\&issn=2320-

$4672 \&$ isbn $=\&$ volume $=7 \&$ issue $=4 \&$ spage $=412 \&$ pa

24. Paul IM, Beiler J, McMonagle A, Shaffer ML, Duda L, Berlin Jr. CM. Effect of honey, dextromethorphan, and no treatment on nocturnal cough and sleep quality for coughing children and their parents. Arch Pediatr Adolesc Med. 2007 Dec;161(12):1140-6.

25. Pourahmad M, Sobhanian S. Effect of honey on the common cold. Vol. 40, Archives of Medical Research. United States; 2009. p. 224-5.

26. Raeessi M, Aslani J, Gharaie H, Karimi Zarchi A-A, Raeessi N, Assari S. Honey with Coffee: A new finding in the treatment of Persistent Postinfectious Cough. Iran J Otorhinolaryngol [Internet]. 2011;23:1-8. Available from: NS -

27. Chung KF. Assessment and measurement of cough: The value of new tools. In: Pulmonary Pharmacology and Therapeutics. 2002.

28. Hawkins J, De Vere N, Griffith A, Ford CR, Allainguillaume J, Hegarty MJ, et al. Using DNA metabarcoding to identify the floral composition of honey: A new tool for investigating honey bee foraging preferences. PLoS One. 2015;10(8):1-20.

29. Smith SM, Schroeder K, Fahey T. Over-the-counter (OTC) medications for acute cough in children and adults in community settings. Cochrane database Syst Rev. 2014;(11).

30. Smith SM, Henman M, Schroeder K, Fahey T. Over-the-counter cough medicines in children: neither safe or efficacious? Br J Gen Pract. 2008 Nov;58(556):757-8.

31. Kenealy T. Sore throat. BMJ Clin Evid [Internet]. 2011;2011:1509. Available from: http://www.ncbi.nlm.nih.gov/pmc/articles/PMC3275136/

32. Arnon SS, Midura TF, Damus K, Thompson B, Wood RM, Chin J. Honey and other environmental risk factors for infant botulism. J Pediatr. 1979;94(2):331-6. 